\title{
Jejunal Lipoma, an Uncommon Cause of Gastrointestinal Bleeding
}

\author{
João Pinto ${ }^{a}$ b Joana Castela ${ }^{b}$ Susana Mão de Ferro ${ }^{b}$ \\ a Serviço de Gastrenterologia, Hospital Amato Lusitano, Unidade Local de Saúde de Castelo Branco, \\ Castelo Branco, Portugal; b Serviço de Gastrenterologia, Instituto Português de Oncologia de Lisboa \\ Francisco Gentil, EPE, Lisbon, Portugal
}

\section{Keywords}

Gastrointestinal haemorrhage · Capsule endoscopy ·

Balloon enteroscopy $\cdot$ Lipoma $\cdot$ Jejunum

\section{Lipoma jejunal, uma causa incomum de hemorragia gastrointestinal}

\section{Palavras Chave}

Hemorragia gastrointestinal · Cápsula endoscópica . Enteroscopia assistida por balão · Lipoma · Jejuno

\section{Case Report}

A 46-year-old male with a past history of arterial hypertension presented with asthenia and melaena. On examination, he presented tachycardia and elevated blood pressure. His blood tests showed microcytic hypochromic anaemia (haemoglobin $6.9 \mathrm{~g} /$ $\mathrm{dL}$ ). After receiving 2 units of red blood cells, the patient underwent upper endoscopy, which was unremarkable except for gastric fundic gland polyps. Ileocolonoscopy revealed only terminal ileum nodular lymphoid hyperplasia.

A capsule endoscopy was done according to the diagnosis of obscure gastrointestinal bleeding. In the 2 nd tercile, after a period of $30 \mathrm{~min}$ of slow progression, a large polypoid ulcerated mass

\section{KARGER}

E-Mail karger@karger.com www.karger.com/pjg
(C) 2018 Sociedade Portuguesa de Gastrenterologia Published by S. Karger AG, Basel

\section{Karger}

0 pen access

This article is licensed under the Creative Commons AttributionNonCommercial-NoDerivatives 4.0 International License (CC BYNC-ND) (http://www.karger.com/Services/OpenAccessLicense) Usage and distribution for commercial purposes as well as any distribution of modified material requires written permission. causing significant luminal deformation was identified (Fig. 1). Antegrade double-balloon enteroscopy was performed and, in the proximal jejunum, a large diverticulum with an ulcerated border adjacent to an ulcerated lesion suggestive of subepithelial origin with approximately $8 \mathrm{~cm}$ (Fig. 2) was detected. On the proximal end, a tattoo was made as a reference mark. Extensive biopsies of the ulcer borders revealed only oedema, capillary proliferation, and regenerative features.

A CT scan revealed, in the proximal jejunum, a target sign with a central component compatible with adipose tissue, consistent

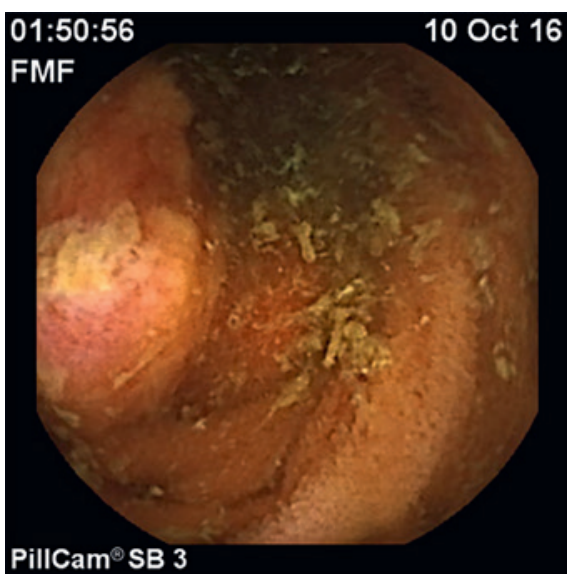

Fig. 1. Capsule endoscopy $\left(\right.$ Given $^{\circledR}-$ PillCam $^{\circledR}$ SB3 $)$ showing an ulcerated polypoid lesion of the jejunum.
Dr. João Pinto

Serviço de Gastrenterologia, Hospital Amato Lusitano

Unidade Local de Saúde de Castelo Branco

Avenida Pedro Álvares Cabral, PT-6000-085 Castelo Branco (Portugal)

E-Mail jsdiaspinto@gmail.com 


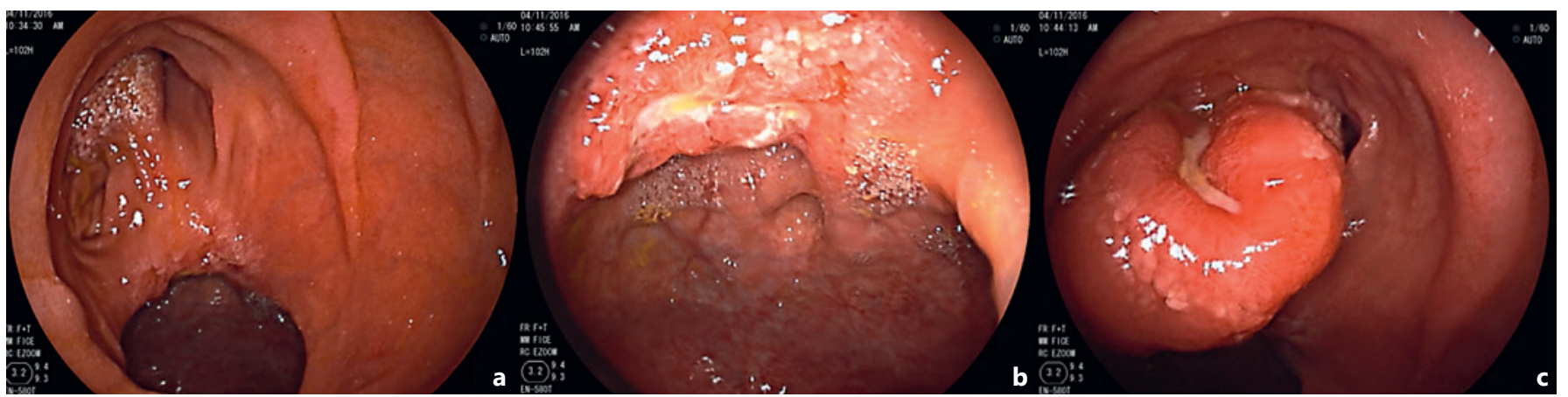

Fig. 2. Double-ballon enteroscopy $\left(\right.$ Fujinon $\left.{ }^{\circledR}\right)$ revealing a large jejunal ulcerated diverticulum (a, b) and immediately after a large ulcerated polypoid lesion $(\mathbf{c})$.
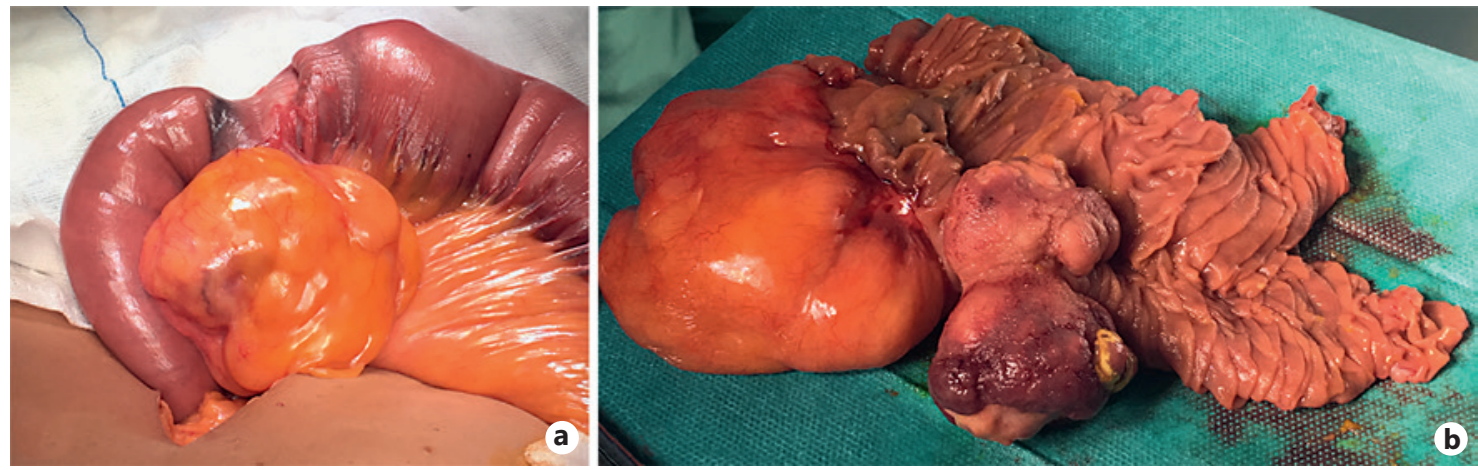

Fig. 3. During surgery, the jejunal tattoo was identified adjacent to a segment of decreased wall thickness and a palpable intraluminal mass (a). Upon exposure of the lumen, these changes corresponded to a large diverticulum and a $7.5 \mathrm{~cm}$ pedunculated ulcerated lesion $(\mathbf{b})$.

with jejunal intussusception, although the aetiology could not be identified. A segmental enterectomy with side-to-side jejunal anastomosis was performed. Intra-operative macroscopic observation identified in the jejunum, just distally to the tattoo, a large diverticulum and a $7.5-\mathrm{cm}$ pedunculated ulcerated lesion (Fig. 3). The histological evaluation showed a submucosal jejunal lipoma with superficial ulceration (Fig. 4). The patient recovered completely and uneventfully.

\section{Discussion}

Lipomas are benign tumours of mesenchymal origin that can arise throughout the gastrointestinal tract. The most common localization is the colon $(65-70 \%)$, followed by the small intestine (20-25\%) and, rarely, the oesophagus and stomach [1-5]. Lipomas are the second most common benign tumours of the small bowel, right after leiomyoma [1].
Small bowel lipomas are typically solitary lesions, more frequently located in the ileum and corresponding to spheroid deposits of adipose tissue confined to the submucosal layer $[2,3,5]$.

Due to its small size and indolent behaviour they usually do not cause symptoms [4]. However, when reaching sizes above $2 \mathrm{~cm}$, they can cause intussusception, bleeding, pain, or biliary obstruction [1,3-5].

Endoscopically, whether by device-assisted enteroscopy or by capsule endoscopy, lipomas generally present as rounded smooth yellow subepithelial tumours with a wide base or pseudopedicle [1-3]. The "cushion sign" and "naked fat sign" $[1,2]$ have also been classically described as specific endoscopic features [1-4].

When symptomatic, there is indication for endoscopic $[3,5]$ or surgical treatment $[1,2,4]$. Endoscopic resection in the small bowel has higher risks, especially with classic snaring technique, requiring higher amounts of 
Fig. 4. Histologic evaluation ( $\mathrm{H} \& \mathrm{E}, 4 \times$ magnification) showing well-circumscribed subepithelial accumulation of adipose tissue. Inset depicts localization in the submucosal layer. M, mucosa; LP, lamina propria; SM, submucosa; MP, muscularis propria; $\mathrm{S}$, serosa.

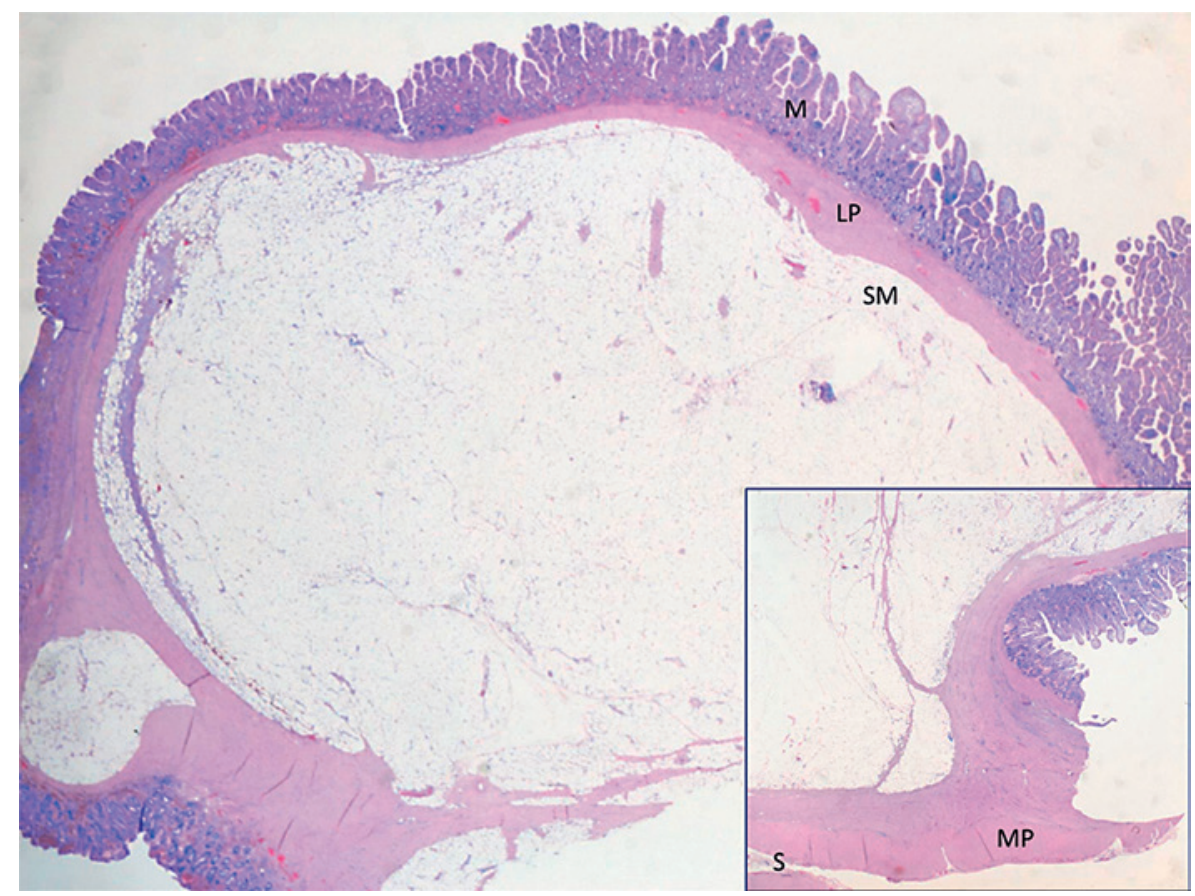

energy due to poor electrical conductivity of adipose tissue. In this context, technical tricks such as the "loopand-let-go" and "unroofing technique" have been described $[3,5]$.

Due to the atypical endoscopic features, dimension, and extensive ulceration, which did not allow for a prompt diagnosis, endoscopic treatment was not considered in the present case.

This case illustrates the difficulties in the diagnosis of obscure gastrointestinal bleeding and small bowel diseases even when all the different diagnostic tools available are used.

\section{Acknowledgements}

The authors acknowledge Dr. João Dinis Silva for granting usage of the capsule endoscopy images.

\section{Statement of Ethics}

The authors declare that no patient data appear in this article.

\section{Disclosure Statement}

The authors declare no potential conflicts of interest with respect to the research, authorship, and/or publication of this article.

\section{References}

1 Kida A, Matsuda K, Matsuda M, Sakai A, Noda Y: A unique case of massive gastrointestinal bleeding. SAGE Open Med Case Rep 2017;5:2050313X17700345.

2 Yatagai N, Ueyama H, Shibuya T, Haga K, Takahashi M, Nomura O, Sakamoto N, Osada T, Yao T, Watanabe S: Obscure gastrointestinal bleeding caused by small intestinal lipoma: a case report. J Med Case Rep 2016;10:226.
3 Toya Y, Endo M, Orikasa S, Sugai T, Matsumoto T: Lipoma of the small intestine treated with endoscopic resection. Clin J Gastroenterol 2014;7:502-505.

-4 Ferrara F, Duburque C, Quinchon JF, Gaudissart Q: Laparoscopic resection of small bowel lipoma causing obscure gastrointestinal bleeding. Updates Surg 2012;64:153156.
5 Ponte A, Pinho R, Rodrigues A, Vale S, Cidade C, Silva J, Rodrigues J, Sousa M, Carvalho J: Endoscopic resection of large gastrointestinal lipomas: loop-and-let-go technique with some twists. Gastroenterol Hepatol 2017;40:465-467. 